\title{
Infection with Human T Lymphotropic Virus 1 is associated with bronchiectasis among Indigenous Australians
}

\author{
Lloyd Einsiedel ${ }^{1,2^{*}}$, Liselle Fernandes ${ }^{2}$, Tim Spelman², Eduardo Gotuzzo ${ }^{3}$ \\ From 15th International Conference on Human Retroviruses: HTLV and Related Viruses \\ Leuven and Gembloux, Belgium. 5-8 June 2011
}

\section{Background}

Infection with the Human T-Lymphotropic Virus 1 (HTLV-1) is associated with bronchiectasis in Indigenous Australians [1]. The present study defines the clinical presentation and outcomes of bronchiectasis according to HTLV-1 serostatus in this population.

\section{Materials and methods}

Retrospective cohort study at Alice Springs Hospital, central Australia. Medical records were reviewed for all Indigenous adults admitted between 2000-2006 with radiologically confirmed bronchiectasis and known HTLV-1 serostatus.

\section{Results}

One-hundred and twenty patients were admitted during the study period, HTLV-1 serology was performed for $92(75.8 \%)$ patients. Western blots confirmed HTLV-1 infection in $52(58.4 \%)$ cases and were indeterminate for 3 patients. HTLV-1 seropositive patients more often had bilateral bronchiectasis (HTLV-1+, 37/ 51; HTLV-1-, 18/36; $\mathrm{p}=0.032$ ) and ground glass opacities (HTLV-1+, 10/51; HTLV-1-, 1/36; $\mathrm{p}=0.028)$ on HRCT chest, but were less likely to have a pathogen isolated during an infective exacerbation (HTLV-1+, 16\%; HTLV-1-, 20\%; $\mathrm{p}=0.042$ ). HTLV-1 seropositive patients were more likely to have cor pulmonale (HTLV-1+, 10/52; HTLV-1-, 1/37; $\mathrm{p}=0.023$ ) and to suffer bronchiectasis-related deaths (OR 5.78; 95\% CI,
$1.17,26.75 ; \mathrm{p}=0.028)$. The mortality rate for the entire cohort during the 7 year period was $34.2 \%$. Median age of death for both groups combined was 42.5 years. Only HTLV-1 seropositive patients were admitted for treatment of infected skin lesions and this was the major predictor of subsequent death from any cause on multivariable analysis (OR, 6.77, 95\% CI, 1.46, 31.34; $\mathrm{p}=0.014$ ).

\section{Conclusion}

In an Indigenous Australian cohort HTLV-1 infection is associated with bronchiectasis and an increased risk of pulmonary hypertension and death.

\section{Author details}

${ }^{1}$ Department of Medicine, Alice Springs Hospital, Northern Territory, 0870 Australia. ${ }^{2}$ Northern Territory Rural Clinical School, Alice Springs, Northern Territory, 0870, Australia. ${ }^{3}$ Department of Medicine, Cayetano Heredia University, Lima, Peru.

Published: 6 June 2011

Reference

1. Steinfort DP, Brady S, Weisinger HS, Einsiedel L: Bronchiectasis in central Australia: A young face to an old disease. Resp Med 2008, 102:574-578.

doi:10.1186/1742-4690-8-S1-A38

Cite this article as: Einsiedel et al:: Infection with Human T

Lymphotropic Virus 1 is associated with bronchiectasis among Indigenous Australians. Retrovirology 2011 8(Suppl 1):A38.

\footnotetext{
* Correspondence: Iloyd.einsiedel@health.sa.gov.au

'Department of Medicine, Alice Springs Hospital, Northern Territory, 0870,

Australia

Full list of author information is available at the end of the article
}

(c) 2011 Einsiedel et al; licensee BioMed Central Ltd. This is an open access article distributed under the terms of the Creative Commons 